\title{
The Technology of Corn Processing as an Effort to Increase The Income of Kelambir V Village
}

\author{
Martos Havena ${ }^{1}$, Leni Marlina ${ }^{2}$ \\ ${ }^{1)}$ Agroecotechnology, Faculty of Agriculture, University of Pembangunan Pancabudi \\ ${ }^{2)}$ Computer Science, Faculty of Computer Science, University of Pembangunan Pancabudi
}

\begin{abstract}
Majority of people in Kelambir V Kebon, Hamparan Perak Sub-district, Deli Serdang Regency work as farmers. Farmers in this area have been experiencing obstacles in marketing their yields if the results are abundant. To solve this problem, some activities will be conducted in the form of: (1) transfer of knowledge, such as lecture and discussion, (2) training, and (3) assistance on the corn processing techniques. The objectives and targets to be achieved through these activities including: (a) the farmers community or group can process their yields optimally, so that the quality is improved and food diversification program can run well, (b) the farmers and the local community in Kelambir V Village can perform the processing techniques of yields skillfully, so they can obtain additional income through the resulting products, (c) the farmers and the local community in Kelambir V Village can maintain health by making corn as an alternative main food product, (d) creating a cooperation between university and community in the form of community service, and (e) being a partner of government in the processing of crops (i.e. corn) into corn processing products to increase income of the farmers. The activities which have been done were location survey, lecture, the implementation of corn processing techniques into processed corn products named dodol, sustainable monitoring, and product marketing guidance.
\end{abstract}

Keywords: Corn, Dodol, Farmers, Fields, Kelambir

Abstrak. Masyarakat Kelambir V Kebon, Kecamatan Hamparan perak Kabupaten Deli Serdang mayoritas berprofesi sebagai petani. Para petani didaerah tersebut selama ini mengalami kendala dalam memasarkan hasil ladang jika hasilnya melimpah ruah. Untuk dapat memecahkan masalah mitra tersebut, maka kegiatan ini akan dilakukan dalam bentuk: 1) Transfer pengetahuan seperti ceramah dan diskusi, 2) Pelatihan dan 3) Pendampingan tentang tekhnik pengolahan jagung. Melalui kegiatan tersebut diharapkan tujuan dan target yang ingin dicapai pada kegiatan ini seperti : a) Masyarakat/kelompok petani dapat mengolah hasil ladang dengan baik sehingga kualitas meningkat dan program

\footnotetext{
*Corresponding author at: Jalan. Gatot Subroto KM 4.5 Medan 20122, Indonesia

E-mail address: havena.martos@gmail.com
} 
diversifikasi pangan dapat berjalan dengan baik, b) Petani dan masyarakat di Desa Kelambir V mampu melakukan tekhnik pengolahan hasil ladang dengan baik sehingga mendapatkan pendapatan tambahan melalui produk yang dihasilkan, c) Petani dan masyarakat dapat menjaga kesehatan dengan menjadikan jagung sebagai produk pangan pokok alternatif d) Terciptanya bentuk kerja sama yang sinergi antara perguruan tinggi dan masyarakat dalam bentuk pengabdian masyarakat, e) Menjadi mitra pemerintah dalam pengolahan hasil ladang jagung menjadi produk olahan jagung sehingga dapat meningkatkan pendapatan petani. Adapun kegiatan yang sudah dilakukan adalah survey lokasi, ceramah, pelaksanaan teknik pengolahan jagung menjadi produk olahan jagung berupa dodol, pemantauan keberlanjutan dan bimbingan pemasaran produk.

Kata kunci: Jagung, Dodol, Petani, Ladang, Kelambir

Received 6 November 2017 | Revised 10 January 2018 | Accepted 13 February 2018

\section{Introduction}

Kelambir V Kebon is one of the villages appointed as the assisted village of University of Pembangunan Panca Budi. One of the livelihoods in Kelambir V Village is being a farmer.

There are several considerations in doing this activity:

1. Raw corn material is the main agricultural product in Kelambir V Village.

2. The processing of corn is relatively easy and simple.

3. It does not require a high level of skill.

4. The crop yields which have low selling value and unsold can be utilized; thus, the farmers will not experience losses and might increase income of the farmers.

5. The processed corn products are considered as the main food which are healthy and delicious. Furthermore, the products are also still rarely found, especially in North Sumatera Province.

6. The use of raw materials from the crops in the form of processed corn products can reduce the consumption of rice, so it can be an alternative staple food.

Based on above considerations, Kelambir V Kebon, Hamparan Perak Sub-district, Deli Serdang Regency has the potential to produce the processed corn products to improve the welfare of the local community in the region. To date, corn has not been optimally managed by the local community in North Sumatera, so that the benefit of corn as the processed products of the local community is still relatively low. The team of the community service expected that this activity could promote corn to be the processed products which can increase the interest and income of the local community. 
Kelambir V Kebon, Hamparan Perak Sub-district, Deli Serdang Regency is a suburban area where the majority of the people work as farmers who rely on cropyields and agriculture [1]. However, the welfare of the local farmers tends to be unstable, not only because the livelihood heavily depends on the season, but also because of the lack of optimal empowerment of farmers. Some of the issues are the abundant amount of crop yields which made it unsold, a low selling value, and improper utilization because the crop yields have a short shelf life [2]. As the processing of crop yields into another processed product has not been optimal yet, it results in low income for the farmers. Therefore, there is a need for a simple technology which can utilize the crop yields optimally and increase the variation of agricultural processed products which have a higher nutrition and selling value. In addition, the technology can be performed by the housewives or wives of the local farmers.

Thus, the overall impact of the technology is expected to be seen in several aspects, such as:

(1) improving the welfare of the local community through the processed crop products into processed food products which have a high nutrition and selling value.

(2) increasing the income of the farmers through the production of the processed food products.

(3) empowering the housewives or wives of the farmers as the producers of the processed food products.

There are several things whichshould be considered in achieving the three aspects and creating Kelambir V Kebon, Hamparan Perak Sub-district, Deli Serdang Regency as a pilot project of the corn producer as an alternative food, such as:

1. A lack of information disseminated to the local farmers.

2. The farmer community has not been introduced to the technology which can optimize the crop yields.

3. The absence of special training on the crop processing techniques into the processed food products.

4. The opportunity for empowerment of PKK groups which generally consist of the farmers' wife as the corn producers.

\section{Methods}

Based on the priority of the problems,the expertise of the proposer or the implementer team, and the agreement about the duration of the activity with the partners which was about 8 months, the approach to solution was to solve the problems regarding the production aspects, especially issues related to the quality of the product, the quantity of crop yields, and problems in the processing of crops. 
The procedure to solve the problems was by conducting training, education, and mentorship for the partners. A questionnaire would also be administered before and after the training to assess the partners' level of understanding. As the duration of the activities was only 8 months, the partners were expected to be able to perform the crop processing independently after the community service was completed. The partners and the team were gathered at one place for a lecture and a direct practice in accordance with the issues to be resolved.

To solve the problems, the implementation of science and technology on corn processing techniques was conductedin the following ways:

\section{Partner I}

1. Lecture and discussion about the prospects and the correct ways of processing the corn

2. Training on how to process corn into corn chips

3. Training on the advantages of each material used

4. Training on the processing techniques to make good and nutritious products

5. Mentoring on the processing aspects to improve the quality and the quantity of the processed corn products

\section{Results and Discussion}

\subsection{Location Survey}

On 27th January 2017, the team of community service surveyed the location at Kelambir V Village / Hamparan Perak, Deli Serdang. The team met with partner I, Mr. Soleh as the head of Kelompok Tani Karya Bersama (Karya Bersama Farmer Community) and partner II. The meeting was intended to discuss about the activities plan of the team including lecture and socialization about agricultural processing products (e.g. corn dodol), training and mentoring in making corn dodol, and discuss about the time and place of those activities (Figure 1).

\subsection{The Lecture on Corn Processing Techniques}

The lecture on corn processing was conducted on 14th March 2017 at the house ofpartner I, Mr. Soleh in Kelambir V Village / Hamparan Perak, Deli Serdang. The participants in the lecture were partner I, partner II, and neighbours of partner I. Before the lecture began, the participants were given a questionnaire to assess the partners' level of knowledge about the processing of corn.

The topics of lecture were:

a. Introduction to the processed corn products 
b. Production the processed corn products (corn dodol)

A module which corresponded to the topic of the lecture was provided in each lecture. The topics of the lecture were about the benefits of corn, the processed corn products, the production of corn dodol, the marketing prospects, and the obtained economic values. The main purpose was to increase the income of the farmers from corn as their crop yields. The participants showed great enthusiasm whichwas shown by the number of participants, the number of questions asked, and the enthusiasm and seriousness of the participants during the lecture.
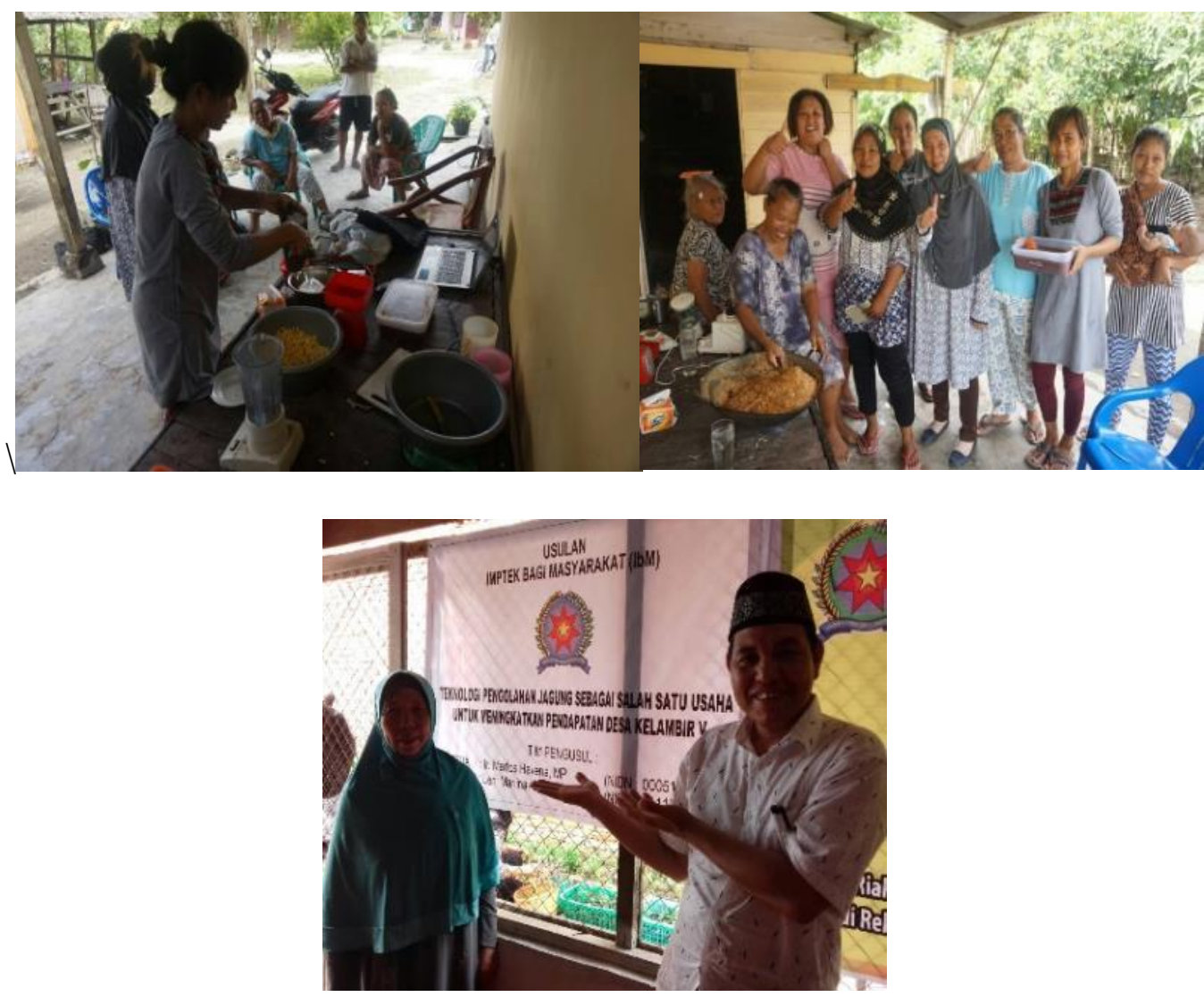

Figure 1. Community Service Activities in Kelambir V Village, Hamparan Perak, Deli Serdang

\subsection{The Corn Processing Techniques}

The activity of processing corn into processed products with high nutritional value was carried out on 9th April 2017 at the house of one of the members of partner I in Kelambir V Village / Hamparan Perak, Deli Serdang. The training was about how to process corn into corn dodol products. The participants were enthusiastic during this activity which can be seen from their active participation in the production of dodol.

\subsection{Monitoring and Guidance of The Product Marketing}

The local community, especially the assisted village will be monitored regularly and will be guided to market their products. Besides, the partners will continue to improve and upgrade the 
taste and the quality of the processed corn products to produce high-quality corn products. Furthermore, they shouldalso continue to innovate in the corn processing to produce innovative and marketable products.

\section{Conclusion}

The activities of community service which have been implemented by the UNPAB team were helpful and beneficial topartner I, partner II, and the participating community. The local community showed great enthusiasm and active participation in the lectures and techniques on the corn processing during the activities. The knowledge of participants about the corn processing also increased. Therefore, the local community, especially the partners received the benefits from the training which has been conducted in their village.

\section{References}

[1] Badan Pusat Statistik. 2014. Profil Kependudukan Provinsi Sumatera Utara.

[2] Badan Pusat Statistik. 2014. Statistik Kesejahteraan Rakyat. Badan Pusat Statistik Sumatera Utara. 